\title{
THE MECHANISM OF HUMOUR UNDER RELEVANCE-THEORETIC PERSPECTIVE
}

\author{
Sídnei Cursino-Guimarães* \\ Uberlândia, Brasil
}

\begin{abstract}
In this paper, I present a model to explain the mechanism of humour, combining the concept of bisociation as proposed by Koestler (1964) with the cognitive and the communicative principles of relevance as proposed by Sperber and Wilson (1986/1995). I suggest that the development of humour occurs by recourse to bisociation, which, in turn, is reflected by the junction of an enthymeme and a paradox. In order to interpret the result of the fusion of these logical procedures in some jokes, I develop an analysis based on the relevance-theoretic comprehension procedure. I finally propose the concept of paradoxical implicated conclusion, a phenomenon that only occurs in humorous genre.
\end{abstract}

Keywords: Communication. Humour. Relevance Theory. Bisociation. Paradox.

1 INTRODUCTION 1,2

I try to explain the mechanism of humour in this paper using the concept of "bisociation" under the scope of relevance theory. For that, I analyse some jokes in narrative form, or in a one-liner format ${ }^{3}$. These texts intend the effect of laughter, excluding ones caused by drugs, laughing gas, tickling, nervousness, etc. Having laughter as a response to the humorous text (or "comic text"), the writer can infer that the reader understood what he read; but, on the other hand, situations should not be considered where the text-intentionally humorous - does not reach its goal, on the reader's side, for causes such as misunderstanding, explicitation of inferences, ideological disagreement with the focused theme, contexts that inhibit the laughter (religious, ethical, etc.).

Relevance theory explains how the individual understands utterances, but this theory is not intended as a specific theory of humour. Similarly, bisociation theory intends to provide a mechanism to explain the forms of creativity, including humour, but it is not a theory that explains the cognitive process involved in understanding utterances. This study aims to conciliate the contributions of both theories, as other

\footnotetext{
* PhD in Linguistics at Federal University of Minas Gerais - UFMG, Belo Horizonte, Brazil. E-mail: sidnei.cursino@yahoo.com.br.

${ }^{1}$ This article sums up my PhD thesis entitled: "The challenge of humour to the seduction of processing the humorous text in the light of relevance theory" (CURSINO-GUIMARÃES, 2008).

${ }^{2}$ I wish like to thank Francisco Yus Ramos for kindly providing me his texts at the beginning of the studies that led to my PhD thesis; Fábio José Rauen for the countless generous explanations about relevance theory; and Anne Reboul for the clarity of discussions about the analysis of jokes.

3 'One-liners jokes' refers (in principle) to jokes of one single line; but I prefer to consider that there are jokes created with one single utterance (which sometimes is written in more than one line), as a maxim or an advice.
} 
authors that sought an explanation for the specific mechanism of humour creation prior to submit the text to "mechanisms of understanding" they have already done.

Sperber and Wilson's (1986/1995) relevance theory starts from an inherent property of human cognition and communication. The authors propose a cognitive principle of relevance, according to which "human cognition tends to be geared to the maximization of relevance;" and, based on this cognitive principle, they propose a communicative principle of relevance, according to which "every act of ostensive communication communicates a presumption of its own optimal relevance" (SPERBER; WILSON, 1986/1995, p. 242).

My proposal for a mechanism to explain the humour under the scope of relevance theory can be summarized in the following topics:

a) In bisociation theory, an interpenetration of cognitive schemas is proposed. In this interpenetration, contextual assumptions yielded from the initial part of the text, being incompatible with assumptions yielded inferentially from the final utterance (called "trigger"), both of them as implicated premises, conflict and merge, producing a paradox (a form of incongruity) as an implicated conclusion $^{4}$, which is the base of humorous texts.

b) The implicated premise ${ }^{5}$ yielded from the trigger will be the premise that is absent in an enthymeme and, because that deductive reasoning exerts a coercion in the interpretive process, the reader is led to the paradoxical conclusion inevitably. ${ }^{6}$

c) The syllogistic structure increases the relevance of the ostensive marks in the text, which limits the possibilities of interpretation and, because this was sought in advance by the speaker, the interpretative way constitutes the route that yields more contextual effects with less processing effort. The conclusions are easier because, following the logic of the enthymeme, they are inevitable. Hence, the reader is allowed to be geared by this route and accepts this paradox, to which he was conducted, as optimally relevant. I propose to call paradoxical implicated conclusion or PIC the paradoxical and implicated conclusion of the humorous text, which characterizes this genre and it is obtained from a third scheme. The use of logical reasoning (the enthymeme) forces the interpretation to this paradoxical conclusion and gives relevance to the paradox, because it makes the most natural conclusion to the assumptions presented. The paradox causes a shock, precisely because it results of a logically-driven reasoning in interpretation: it is an explanation, but it is paradoxical. The shock seems to result from the fact that reader needs to fuse two ideas, building a bisociation to interpret.

\footnotetext{
${ }^{4}$ This concept will be discussed later.

${ }^{5}$ Idem.

${ }^{6}$ I applied a test of humor cancellation to 4th year students of the Letters Course at the University of Patos de Minas - UNIPAM, in which I proposed to those informants to eliminate the humor of the text. Systematically, the elimination of humour coincided with the elimination of the trigger.
} 
d) The paradox cannot be solved: it is created in joke to be maintained. Establishing a parallel with a surrealist framework is not expected that the blocks of representations presented here are apprehended as distinct realities: the overlap should be perceived as a whole. Likewise, it is not expected that the color green is dissected in its primary colors, blue and yellow. The same interpretative procedure is expected from the overlap of ideas, which constitutes the paradox in the joke and, therefore, cannot be "dissected" into coherent blocks of meaning. ${ }^{7}$

e) The apprehension of the elements that yield the paradoxical structure is intuitively understood by the reader/listener, but its paraphrase, which I call "summary-sentence of the incongruous idea," is matter of competence of the linguist.

\title{
2 THE MECHANISM OF HUMOUR - THE BISOCIATION
}

Authors who have approached the humour in relevance-theoretic terms (cf. YUS RAMOS, 1997; CURCÓ, 2003) have proposed as a specific mechanism of humorous text the "cognitive dissonance" - psychological approach disclosed by Festinger (1957, p. 25.), according to which "two cognitions are considered dissonant with each other when they do not fit with each other, i.e., they are incompatible."

I believe that the creation of incongruity goes further, as proposed by Koestler (1964, p. 80), i.e., 'the reader realizes a 'dissonance,' and constructs a bisociation from it." He defines this phenomenon as follows.

\begin{abstract}
The pattern underlying both stories is the perceiving of a situation or idea, $L$, in two selfconsistent but habitually incompatible frames of reference, $M_{1}$ and $M_{2}$ (Fig. 2). The event $\mathrm{L}$, in which the two intersect, is made to vibrate simultaneously on two different wavelengths, as it were. While this unusual situation lasts, L is not merely linked to one associative context, but bisociated with two.

I have coined the term "bisociation" in order to make a distinction between the routine skills of thinking on a single "plan", as it were, and the creative act, which, as I shall try to show, always operates on more than one plan. (KOESTLER, 1964, p. 35-36. Koestler's italics).
\end{abstract}

The author notes that, in the ordinary course of disciplined thought, two matrices or schemes never work simultaneously, i.e., in an "expected" communication, there is always a search for coherence. This notion probably corresponds to the mechanism that the American psychologist Guilford (1982, p. 19) calls "convergent thought." The convergent thought corresponds to "look for a proper solution, but with no escape from rationality," while "using the divergent thought is to seek multiple solutions, including

\footnotetext{
${ }^{7}$ According to Suls (1972), the discovery of the incongruity does not end the interpretation of the text. For that, the recognition of how we built the paradox is needed. This step I see as a "coherentisation" of the incongruence. I disagree with this approach, because I believe that the recognition of the paradox itself means understand it in such a way.
} 
those that do not seem rational and, often, take effect." This last form is related to the cognitive mechanism of bisociation, whose similarity is observable in the statement of Koestler (1964, p. 80): "The creative act of the comedian is to cause momentary fusion of two normally incompatible matrices in a paradoxical synthesis." And, "in the mental disorder that follows, the emotion, abandoned by reason, flows in laughter." I only disagree with the statement about "the emotion to be abandoned by reason." I believe there is an irreversible logic process - which the reader cannot escape and which is still forced to participate - that promotes the surprise caused by this "logic trap" and, as an escape valve, leads to laughter. The L point, which leads to the two schemes of reference, is the final utterance - the trigger (cf. RASKIN, 1985) - so called because it puts in action the bisociative process.

The concept of bisociation was developed by Koestler (1964, p. 21) to explain the manifestations of creativity in Art, Science and Humour. With this concept, the author proposes the "forced" fusion of two incompatible schemes or matrices, generating a third paradoxical (incongruent) scheme. From my point of view, this is the way which best explains the humour in both "invented" and improvisational jokes.

Normally, Koestler (1964) analyses the nature of the matrices $\mathrm{M}_{1}$ and $\mathrm{M}_{2}$ as different forms of ideology, metaphorical context versus another, or as two different codes of behaviour. However, to distinguish the two schemes (matrices) in contrast, I think that it would be more appropriate (by the scope) using the philosophical pair "appearance/reality," as proposed by Olbrechts-Tyteca (1974, p. 322). The term "appearance" corresponds to an error, an illusion, a myth or a dream, while the term "reality" corresponds to assumptions that can be drawn from common sense.

I argue that the paradox of the joke is built on logical grounds: one enthymemewhich being a form of syllogism, leads the reasoning to an inevitable conclusion, making use of inferences to complete one of the premises - and a paradox that is mixed with the above mentioned form of syllogism.

It is worth to note that these two logical procedures do not necessarily come together. An example of paradox without using enthymeme is the following: "Auction license to hunt rhino creates controversy in the U.S. [...] Millionaires disputed the right to hunt a rhino-black that lives in Namibia. According to the country, the money is used in hunting preservation of the species. ${ }^{\prime 8}$ Likewise, there are enthymemes which are not associated with paradoxes in equally "serious" texts, as in the following example: "That politician is a thief. He should be in jail."

Next, I apply the concept of bisociation to explain the mechanism of humour. I use formulas to represent the elements that merge to each other in the process which begins with the first matrices.

Let us analyse the joke number (1):

\footnotetext{
${ }^{8}$ Available at: http://noticias.r7.com/videos/leilao-de-licenca-para-cacar-rinoceronte-cria-polemica-noseua/idmedia/52d474cb0cf2e1de56b0bb0f.html. Access on: 10 March 2014.
} 
(1) A Brazilian guy asks a Portuguese:

- Please! Have you seen someone bending this corner, just now?

- No, sir. When I arrived, it had already been bent. ${ }^{9}$

In this joke, there are two schemes: $\left(\frac{A X}{C}\right)$ and $\left(\frac{A Y}{T}\right)$, where $\mathrm{A}$ is the verb "to bend," "X" and "Y" are the semantic features that differentiate the two uses of the verb. Only the schema (context) " $\mathrm{C}$ " of the things possible to be "contoured" admits the sense "AX"; and only the scheme "AY" of the things possible to be "twisted" admits the sense "AY." On the trigger (mark of bisociation), when the semantic feature "Y" is forced to context " $C$ " (as evidenced by the use of passive voice) has become a third scheme: $\left(\frac{A X Y}{T}\right)$ of the bisociation.

To demonstrate the phenomenon of bisociation, I present two graphical representations with two ovals, which can be explained as follows: the first two initial or source schemes are located on both sides, while, at the intersection of the two source schemes in the centre, there is the schema that results from the superposition of ideasthe formula corresponding to the paradox. The first representation (Figure 1) reproduces the formulas used to represent the bisociation of the joke (1), inserting them into the corresponding places in the graphical schema to interpret the abstract phenomenon of bisociative schema materially:

\section{Figure 1 - Representation of bisociative schema by formulas}

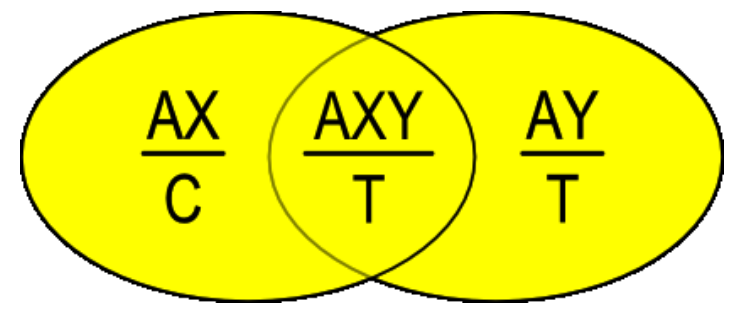

Following, the second graphical representation (Figure 2), I replaced the formulas in Figure 1 by expressions (that sums up the ideas of that scheme), to make clear that the superposition of the source schemes results in the intersection (scheme 3), i.e., in bisociation, translated by summary-sentence of the incongruous idea. This sentence begins on the trigger and it is supplemented by inferences that the trigger refers to: "If the corner had already been bent, it is because someone twisted it, so as to cause a bend," or "in order to make it a corner" (which is tautological). Although the trigger is situated at the base of the incongruous idea, it needs to be supplemented with the yielded inferences at the end of the text, implicated premises, because this element is

\footnotetext{
9 (1) Um brasileiro pergunta a um português:

- Por favor! O senhor viu alguém dobrando esta esquina, agora há pouco?

- Não, senhor. Quando aqui cheguei, ela já estava dobrada.
} 
not alone in the idea which sums up the incongruity caused by the bisociation. The recovery of the incongruent utterance (in its completeness) corresponds to the implicated conclusion in relevance-theoretic terms.

\section{Following, the second graphical representation (Figure 2)}

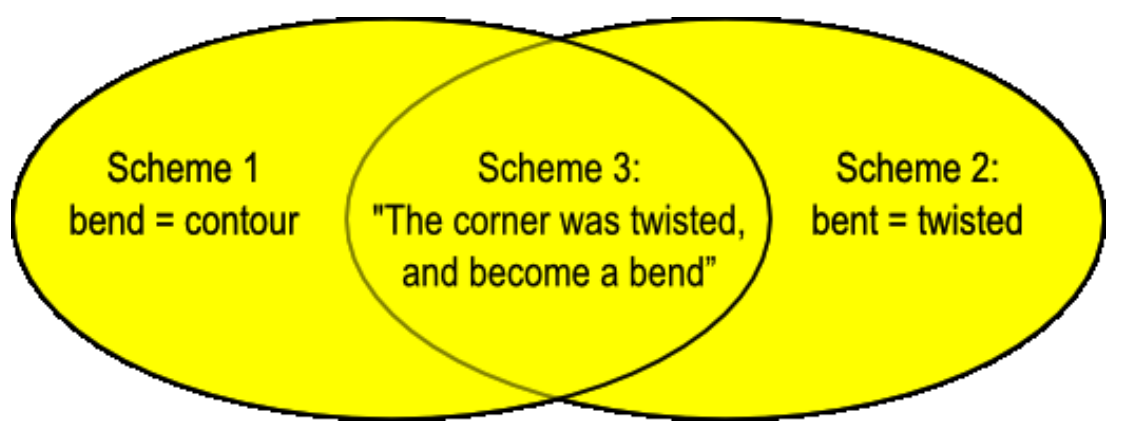

3 THE ORGANIZATION OF THE MECHANISM OF HUMOUR BY MEANS OF A LOGICAL RESOURCE

The model of the mechanism of humour I propose here suggests that incongruous text is structured as an incomplete logical reasoning, the enthymeme, which ends when the trigger is supplemented by inferences, yielding a third cognitive scheme composed of a paradox, as in bisociation theory (KOESTLER, 1964).

According to Blakemore (2005/1982, p. 25), "the idea that communication is governed by norms which have their basis in human rationality is due to the philosopher H. P. Grice (1975, 1982)." I believe that is worth to the speakers both, informal inferences and logical schemas, since they seek to represent the rationality of language precisely. Based on this view, I suppose the humorous text appeals to an enthymeme and a paradox that I try to conciliate with relevance theory.

\subsection{THE ENTHYMEME - PART OF THE FORMAL STRUCTURE OF THE JOKE}

Noguez (1969) argues that humorous language has often seemed to him the appearance of an incomplete reasoning and constituted, therefore, an enthymeme. The author notes:

\footnotetext{
First, the humour always avoids making a judgment. It behaves as an enthymeme, which means a syllogism which lacks the major premise and conclusion; we have only a minor premise, and we can only reconstruct the whole reasoning from the values system of the humourist, that constitute the major premise system. The conclusion result, inevitably, as properly formulated throughout syllogism (NOGUEZ, 1969, s. p.).
}

I quote here an analysed example: 
(2) The official time is from Brasília, so the Brazilian people do not need to work on Mondays and Fridays. ${ }^{10}$

In this utterance, there are:

(a) Major premise: The official time is from Brasília.

(b) Minor premise: Now, in Brasilia, nobody works on Monday and Friday.

(c) Conclusion: So, the Brazilian people do not need to work on Monday and Friday.

By confirming Noguez's (1969) hypothesis, I emphasize the fact that the enthymeme points to aspects of the logical structure (and, consequently, formalsemantic structure) of the joke, including the possibility of generation of inferences that complements the missing term.

I just disagree with the author about the premises that are suppressed, because I have found examples where both, the conclusion and major premise, are not always eliminated. However, I agree with the fact that the premise that is missing is inferred from the system of humourist values, i.e., it is sought in the speaker's world knowledge (as common sense).

Kerbrat-Orecchioni (1998, p. 166) suggests there to be a logical competence, parallel to other skills that the speaker have to process communication. She points two aspects of this logical competence: operations belonging to formal logic (like syllogistic reasoning) and specific operations of "natural logic" (inferential operations). She remembers that, if the standard syllogism is rare in everyday language, enthymemes, in contrast, are frequent.

However, the inferential knowledge occurs through arguments or reasons, but relevance theory argues that, in the proposed rules for human deductive inference mechanism, although there is a logical structure, this logical structure is constructed based on factual assumptions. Sperber and Wilson (1986/1995, p. 121) argue that individuals use non-demonstrative inferences in ordinary language, and the reader identify implications of any utterance from information extracted from their previous knowledge is an example of this type of non-demonstrative inference. It is therefore different from the demonstrative inferences, which are obtained by applying deductive rules (logic) to a set of premises provided previously.

Non demonstrative inferences are those that cannot be evaluated in terms of validity, as logical inferences, and cannot be explained by logical processes that may confirm them, but by the way in which these inferences are yielded and confirmed. According to Sperber and Wilson (1986/1995, p. 119), "a non-demonstrative inference only generates all interesting conclusions, not demonstratively supported by a set of assumptions." In other words, it generates non-trivial conclusions, which means that redundancies are discarded and, by the same process, contradictions are eliminated. So, the best the receiver of a communication can do is go through the following two stages of the process: the formation and the confirmation of hypotheses, considering that the

\footnotetext{
${ }^{10}$ O horário oficial é o de Brasília, então o brasileiro não precisa trabalhar na segunda e na sexta.
} 
inference, as it is done in daily communication, is better described as a sort of conjecture. This conjecture can be successful or unsuccessful, but never valid or invalid as occurs under the logical point of view.

On the other hand, the authors suggest that, for deductive synthetic rules, as occurs with the enthymeme, it must apply alternative forms, derived from regular synthetic forms, but better conformed to the process of generating inferences in human communication. The optional rules suggested by them are: conjunctive modus ponens and disjunctive modus ponens. The conjunctive modus ponens, with elimination of the "if" of a complex premise (joint assumptions) has the following formulation (SPERBER; WILSON, 1986/1995, p. 145)

Conjunctive modus ponens
(a) Input:
(i) (if (P and Q) then R)
(b) Output:
(ii) $\mathrm{P}$
(If Q, then R)
(a) Input:
(i) (if (P and Q) then R)
(b) Output:
(ii) $\mathrm{Q}$
(If $\mathrm{P}$, then R)

Taking the conjunctive modus ponens scheme above, the enthymeme of the example (2) can be inserted into these deductive rules ${ }^{11}$, as follows:

$\mathrm{S}_{1}-$ The official horary is from Brasília
$\mathrm{S}_{2}-$ In Brasilia, nobody works on Mondays and Fridays.

By conjunctive modus ponens, we have:

$\mathrm{S}_{3}-\mathrm{S}_{1} \wedge \mathrm{S}_{2} \rightarrow \mathrm{S}_{4}$

This can be translated as:

$\mathrm{S}_{3}$ - If the official horary is from Brasilia and nobody works on Mondays and Fridays in Brasilia, then $\mathrm{S}_{4}$.

This allows implicating the conclusion.

$\mathrm{S}_{4}-$ Brazilian people do not need to work on Mondays and Fridays.

\footnotetext{
${ }^{11}$ Referring to the mechanism or deductive module in the interpretation of utterances, in which Sperber and Wilson "argue there were only elimination rules of type 'elimination-and' and modus ponens", Rauen (2008, p. 199, footnote 5) notes that "sometimes it is possible to combine the two rules for conjunctive modus ponens": "( $\mathrm{P} \wedge \mathrm{Q}) \rightarrow \mathrm{R}, \mathrm{P} \rightarrow \mathrm{R}, \mathrm{R}$," or then "( $\mathrm{P} \wedge \mathrm{Q}) \rightarrow \mathrm{R}, \mathrm{Q} \rightarrow \mathrm{R}, \mathrm{R}$." Given the clarity of his methodology, I choose to embrace it.
} 
Whereas the speakers keep predictions about the continuity of speech in a communicative exchange, the incongruity caused by rupture of these predictions, in an opposite direction, points to what is trivially called "common sense," and appears as a background (including linguistic knowledge, beliefs and values) shared by individuals. In this place, the assumptions with which the reader will complete the enthymeme are encountered. Therefore, a background of normality is necessary for the confrontation (and recognition) of incongruity: the suspension is provided for the fact that humour inverts the norms, against the assumptions maintained in this background and tacitly accepted by most individuals.

In relation with common sense, it can be stated that the inconsistency in the joke does not equate to some kind of inconsistency related to ungrammaticality of the sentence; it is, specially, a pragmatic inadequacy: it is an element that is seen as incongruous, paradoxical, dissenting in relation to an initial context, since it refers, usually, to the beliefs that are held by the speaker's community.

Reboul and Moeschler (1998, p. 116) observe that, for the notion of belief, Sperber and Wilson use the term 'assumption', in English, which appropriately says what it means, i.e., it is not for sure. They insist, therefore, on the fact that "the propositions entering the representation of the world generally consist of beliefs, rather than knowledge, i.e., they are often fallible and may prove to be false" (REBOUL; MOESCHLER, 1998, p. 117).

If, according to relevance theory, the most significant assumptions are the first assumed to the reader in the step of the interpretation process, I can conclude that it is, then, the belief (the first assumption accessed by him) which will oppose with the idea initially presented by the humorous text, yielding the incongruity.

Assumptions that the text convenes are based on common sense and form a set of expected information that the bisociation comes to contradict (cf. "determinism rupture" of FOURASTIÉ, 1983). According to Voese (1990, p 13), "the comic effect [...] comes from the simultaneous presence, in the receiver's mind, of social reality that is familiar to him and its distorted reproduction." I consider that, precisely because of this "common sense," which, on the one hand, makes possible the communication (and enables possible "expectations" of which the theory of mind refers to), but, on the other hand, gives to reader the feeling of being controlled by the system, is that the laughter should be considered linked to social circumstances. I called the rules which govern the comic as "rules of social life," because they correspond to all and any kind of tacit regulation with which the social system controls the individual. I describe them as the unspeakable, which is embarrassing for the social group.

These rules concern to certain themes that, for the most people, are true taboos (which I will not detail by the restriction of this space) which, in summary, are utterances or attitudes that explicitly compromise the own face or the others people's face who are in communicative exchange. They are rules whose violation is only taken with impunity by means of humorous stories and, in the Eco's words (1984, p. 346), "the rule that is violated by a comic text is well known, that there is no need to reinforce it", i.e., the censure made by the humorous text reveals the easily identified inadequacies in the social system, but this remains unchanged. The recovery of the 
mentioned rules, as I have already noted, is done through inferences from the trigger. This hiatus (the "unspeakable", which is precisely the element pointed and criticized by the joke) to be recovered by the reader, probably occurs for the reasons quoted from Kerbrat-Orecchioni (1998, p. 170), when she explains the point of view of Ducrot (1972, p. 8) and Flahault (1978, p. 45) about the implicits.

\footnotetext{
The own absence of the implicited assertion gives it a presence of a particular type, and "makes it highly prized": doubtless because it requires a larger interpretive work on the part of the reader, that should to exhume it from the textual depths; is in fact very often on their implicit contents that focus the utterances (my italics).
}

I agree with the fact that the information acquired by inference requires less processing effort and becomes more relevant. Thus, in the case of automatically triggered inferences, as in the case of enthymeme, I believe that the inferences are more relevant precisely because they require less processing effort. When the enthymeme is completed in the joke, the reader is naturally led to accept the paradox that results from processing the text. I believe that the reasoning forced to the absurd conclusion (the paradox) provokes laughter.

\title{
3.2 THE PARADOX - BASIC STRUCTURE OF HUMOUR
}

My intention is to seek, in the paradox understanding, the justification for the fact that it can be assigned this name (and its characteristics) to the incongruity created by the trigger of humorous stories.

From the narrower concept of contradiction, which is more usual today, the term "paradox" is equivalent with "incongruity." So I will use one or other of these terms to refer to the same concept.

Trying to distinguish what characterizes the paradox, Vidal-Rosset notes that

\begin{abstract}
the specificity of the paradox is that it reposes about premises that are considered as true, but with help of which one comes to the proper way to a conclusion that, in a more or less obvious way, contradicts both logic and sensitive evidence. It is because the paradox is, above all, of a logical nature: it cannot doubt the reasoning that leads to the paradoxical conclusion and speculate the reasons why it gets logically to contradict the evidence [...] as Quine points out: 'a surprise that brings an antinomy cannot be prevented by nothing but the rejection of a part of our conceptual heritage' (2004, p. 9, my italics).
\end{abstract}

Watzlawick, Beavin and Jackson (1981 [1967]) give special attention to the paradox when they investigate the psychological and social phenomenon of communication. They argue that, for human beings, no communication is an impossibility (point of view already in compliance with relevance theory) and postulate that there is a condition for the communicative act: that it does not just convey information, but it simultaneously conveys a relationship that requires from the receiver a behaviour, because it gives indications of how the message should be considered, suggesting a kind of "pragmatic conditioning" established between the interlocutors. This relationship, according to them, should be considered as a meta-communication. 
These researchers reported a Bateson's study (1954, p. 230) in which he observed two monkeys "faking a fight." Bateson observed that "the signs and actions alone have been considered similar to a fight, but it was clear that the sequence as a whole was not a fight." This led him to conclude that "this playful phenomenon could only occur if the organisms were capable of some degree of meta-communication, i.e., exchange of signals that convey the message 'this is a game.' Examining this implicit message, the researcher concluded that this apparent paradox (a fight that was not a fight) could be explained in terms of "language and meta-language," which could be extended to other paradoxes, such as those created by the humour.

According to Watzlawick, Beavin and Jackson (1981, p. 232), to apply this observation to the utterance "this is a game," it would get an explanation (paradoxical) more or less as follows: "These actions we are now engaged does not denote what these actions that they represent could denote." This interpretation of the paradoxical action stands for, in my point of view, the summary-sentence of the incongruous idea, that I proposed since the beginning of my research on humour in 2001 to interpret the bisociation of jokes.

The researchers highlight the fact that there is something in the nature of the paradox that has a pragmatic and even existential importance for individuals. According to Watzlawick, Beavin and Jackson (1981 [1967, p. 167]), is the own bisociation that provides the premises of this logical mechanism. It is the reason why they argue that, in the joke, this kind of "reasoning" takes place on two levels, as proposed by Koestler. Although this author considered the following comparison nowhere in his book, those researchers suggest that the bisociation has the structure of the paradox, i.e., the "two reference frames inherently coherent, but habitually incompatible" from the definition of Koestler would be in a relationship of level: "use" (or "object-level") and meta-level ("mention"). According to them, in the paradox, there are two utterances: one is in the object level and the other in the meta-level (meta-language). If the term "mention," is replaced by a broader concept of "interpretation" in relevance theory (cf. SPERBER; WILSON, 1986/1995, p. 350), even so, I believe that still prevails an idea, similar among researchers of paradox (connected or not to the humour), that there is the use of two levels of interpretation in it. In my proposal, this perspective would be considered to the first two schemes (seen as "coherent") as an object-level of language and the bisociated scheme (incongruent) as a meta-level or "interpretive use" of language.

The relationship between the paradoxical elements is not always clear. However, under the chart of oppositions or table of logic contradictions, it is possible to distinguish both, ideas that maintain relations of contradiction or opposition and forms of implication, from which paradoxes can be created (issues proven by analysis which will be not included here).

Most of the authors adopt three general classifications for the paradox: logical paradoxes (specific of Logic and Mathematics, which are beyond the interest of my research), semantic paradoxes and pragmatic paradoxes. Récanati (1979, p. 193-215) explains the paradox, taking as its starting point the synthetic and analytic propositions. If a paradox may come either in a single proposition as the conclusion of an argument, it can be classified in two ways: it can be a mismatch created in the linguistic system, 
consisting in a semantic paradox (example 3), which means that the contradiction arose in level of analytical inferences; or it can be a mismatch created between propositions whose inadequacy is yielded by the relationship of terms relating to their utterance, consisting in a pragmatic paradox (example 4), which means that the contradiction arises in level of synthetic inferences, being necessary to appeal to the world knowledge to detect them.

(3) Hypochondriac is the man who feels good only when you feel bad (OSCAR WILDE, s.d.). ${ }^{12}$

(4) There are three kinds of people: those who can count and those who cannot. ${ }^{13}$

In example (3), at the level of utterance, the expression "feel good" clashes with the expression "feel bad," that is conflicting with the specification of the first definition. In example (4) the utterance and the enunciation are contradictory and, to understand it, the reader needs to trigger inferences from their pragmatic knowledge (of the world).

I believe that is essential to consider the fact that the paradox in the joke is not designed to be "undone." Like all results from any creative process, it should to be kept, showing the lucid spirit of those who created it and the challenges of reasoning that are proposed to the reader.

All the arguments that I have developed aim to prove that is the paradox that underlies the joke, and it becomes more relevant by the way how the text is structured, i.e., in the form of an enthymeme, so that the reader is inexorably led for the incongruous conclusion. The model that I propose for the humour text starts, then, from the concept of bisociation (paradox) associated with an enthymeme and fulfilled with relevance-theoretic elements to clarify certain gaps of the theoretical suggestion of Koestler (1964). I shall describe, for each item, the characteristics of this model.

\section{EXPLANATION MODEL OF THE MECHANISM OF HUMOUR: THE CONCEPT OF BISOCIATION UNDER RELEVANCE-THEORETIC PRINCIPLES}

The model to explain the mechanism of humour that I propose is grounded in seven propositions. I start of the combination of these two basic procedures to create humour - the paradox and enthymeme - and submit these mechanisms to the principles of interpretation suggested by relevance theory.

(1) The humorous text presents two cognitive source schemas (both "coherent"): the first is formed by contextual assumptions processed in the part of the text that precedes the final utterance, the trigger; the second scheme, absent and not entertained yet, arises when the new contextual assumptions are accessed inferentially, the trigger being the starting point.

\footnotetext{
12 (3) Hipocondríaco é o homem que se sente bem somente quando se sente mal (Oscar Wilde, s.d.).

${ }^{13}$ (4) Há três espécies de pessoas: as que sabem contar e as que não sabem.
} 
(2) The incongruous idea, which is the third scheme, arises from the association of contextual assumptions from both the text (because the trigger) and the reader's knowledge of the world, yielding implicated assumptions, which are related to rules of social convention. The fact that these assumptions are yielded by an inferential process shows that the humorous text is structured as an enthymeme. The trigger acts as a "link" between these two initial schemes and this binding enables the overlay of incompatible ideas (forced fusion), forming a paradox, which is the third cognitive scheme. This third cognitive scheme can be paraphrased by a "summary-sentence of the incongruous idea," which synthesizes the paradoxical implicated conclusion. This third scheme stems from the trigger and is only known from it, but the trigger is not alone in the paradoxical idea. The idea that prevails in this third scheme has usually a counterfactual nature (is the unusual, or the actual of the philosophical doubles), as opposed to the two sources schemes which are factual worlds (or the appearance of philosophical double, why human beings often unreasonably leaves). Hence one states that the paradox reverses the relationship of the world, showing its true face.

(3) The implicated (and paradoxical) conclusion from the third scheme, different from the "explanations" and commonly causes used in communication, shock precisely because it is a "paradoxical explanation." And, by "explaining" the incongruous, i.e., because the incongruity is the result of a logical process, the discovery of the incongruity causes the laughter.

(4) The inferential processes that the speaker uses informally force the acceptance of the paradox, i.e., as this is the result of a reasoning process that yields inferences of a cognitively "safe" mode, even an incongruous idea, produces contextual relevant effects due to the nature of the phenomenon, so the paradox cannot be undone. It is created to be kept, without being disintegrated into "coherent" parts.

(5) The paradox of humorous text can be semantic or pragmatic. It is semantic, when restricted to the system level, being yielded by analytical inferences; and it is pragmatic, when the facts are not consistent with the discourse, being yielded by synthetic inferences (in which the discourse is put to the test by relating the actual or possible world). The relationship of opposition that yields this third scheme can be established in different ways: they can be contrary or contradictory ideas, or there may be a shock even in a relation of implication.

(6) Whereas the conclusion constitutes an implicated conclusion and it is, in the joke, at the same time, a paradoxical element, I propose that in the humorous text, it must be called Paradoxical Implicated Conclusion - PIC. This conclusion would be showed in a form of a paradoxical utterance that characterizes this genre of text: the summary-sentence of the incongruous idea, which I have been suggesting throughout this study.

(7) The jokes have, in the discursively created incongruity, a critique of the inconsistencies of the socio-political-cultural system in which speakers are inserted, reason why the speaker is usually led, at the end of the text, to verify the relation between the paradoxical implicated conclusion with the "violation of the rules of social conviviality." In many jokes, is the recognition of these violated rules that produces more contextual effects, leading the reader to seek the critique that is in the speaker's intention. 
Considering these propositions, I analyse an example, according to the steps provided by relevance theory, and then seek its paradoxical implicated conclusion PIC. At the end, I also present the same type of graphic scheme that was demonstrated in the joke (1), with the bisociation or paradox in the centre, containing the summarysentence of the incongruous idea, just at the point of intersection and superposition of the two source schemes.

In order to facilitate the analysis of the evolution of in the interpretation of a joke according to relevance theory, I will use the following abbreviations:

$\mathrm{S}$ - for sentence;

CA - for contextual assumptions, searched in the speaker's knowledge of world and required by the utterance processing, to constitute, together with the utterance itself, the interlocutors' mutual cognitive environment;

IP - for implicated premises, i.e., initial inferences yielded from the knowledge of the world required by the utterance, or explicature utterance; information that I consider partial conclusions ("partial," because they only point the way to the reader gets the intention of the speaker; "conclusions," because they derive from reasoning), which will assist in processing implicated conclusions;

IC - for implicated conclusions, or inferences yielded from the implicated premises by the utterance being processed and added to the preceding context; and these findings are analysed for their truth value, considering that the conclusion inherits its strength and the weaker assumption and that force, according to RT, depends on how the hypotheses were acquired; ${ }^{14}$

PIC - abbreviation for paradoxical implicated conclusion, concept which I propose to add in the analysis of jokes. It constitutes a decisive item for understanding the joke mechanism, because it submits the final paradox at the final implied conclusion and it corresponds to the summary-sentence of the incongruous idea.

See the joke:

(5) The truck driver had some provocative words on the bumper: “I don't carry prostitute or police." At the police station, the grumpy patrolman stopped the truck and said:

- Or you erase it or the truck will be seized!

In the following week the patrolman was checking if the truck driver had taken what was written on the truck. Then, he read the following: "I have erased, but I do not carry!" 15

The steps were so developed: in (A), contextual assumptions were extracted from the lexical entries; in (B), implicated assumptions were presented from the first assumptions; in step (C), a new survey for contextual assumptions was made, starting

\footnotetext{
${ }^{14}$ It is worth mentioning here Rauen's comment (2008, p. 200) that "a new information is successively weaker when obtained by perceptual input, by linguistic input, by activating stored assumptions in memory or inferences derived from other information."

15 (5) O caminhoneiro tinha no para-choque dizeres provocativos: "Não carrego prostituta nem polícia". No posto policial, o patrulheiro mal-humorado parou o caminhão e disse: - Ou você apaga isso ou o caminhão fica apreendido! Na semana seguinte o patrulheiro foi conferir se o motorista havia tirado o que estava escrito no caminhão. Então, leu o seguinte: "Apaguei, mas não carrego!"
} 
from encyclopaedic entries compared to the premises (B) ${ }^{16}$; in (D), new contextual assumptions were raised, taking the interpretation until this point and the final utterance of the text; finally, two implied premises from the text were explained, P.1 and P.2, that leading to the implicated conclusion - IC.

As proposed in my theoretical model (and to keep the nomenclature of relevance theory), I add the following step, in which is elaborated in the sentence that interprets the paradox and reveals its humorous character, i.e.: a summary-sentence of the incongruous idea, or a paradoxical implicated conclusion - PIC (and that explains why the text is laughable). And, according to what has been suggested by the analytic characteristic, this PIC (summary-sentence of the incongruous idea) would be more likely the responsibility of the linguist, although the reader perceives this incongruity (and the proof is his/her laughter).

It follows the interpretation of the text (5):

(A) From the encyclopaedic entries "truck driver" and "truck bumpers phrase," are made some hypotheses (CA), which (somehow) reflect truck driver's spirit, their emotions and their beliefs:

(A.1) If he is romantic, the sentence will be about the lack of those whom he loves: his home, his soccer team, etc. "I work with my family to serve yours," for example); ${ }^{17}$

(A.2) If he just wants to have fun, the phrase will have humour, in which case they may have any topic or theme about sex (about women who hitch a ride, as in this example: "I only give a ride to anyone who gives me one") $;^{18}$

(A-3) If he wants to attack (with or without humour), the phrase will be about policy, or the rival soccer team (for example, in the truck's bumper that's carries pigs refrigerator: 'I'm not Palmeirense, but I charge the supporters"). ${ }^{19}$

(A) The sentence of truck's bumper in the text is the assumption (A-3), case in which the assumptions (A.1) and (A.2) falls down.

(B) From the two encyclopaedic entries: "prostitute" and "police," are done the following hypotheses (CA):

(B-1) People normally nourish prejudices (explained in text) against prostitutes, to consider them immoral people;

(B.2) Although normally people do not say, they also have prejudices against police officers, especially those which work in checkpoints and accept gratuities to not denounce found irregularities in vehicles;

\footnotetext{
16 The encyclopaedic entry, as Sperber and Wilson (2001, p. 144) say, "contains information about the extent and/or denotation of the concept: that is, on the objects, events and/or properties that represent it:" finally, all the ideas are associated with the term, forming the so-called 'cognitive schemata' (including, scripts, frames, etc.) - or 'chunks', according to relevance theory.

17 "Trabalho com minha família para servir a sua."

18 "Só dou carona para quem me dá."

19 "Não sou palmeirense, mas carrego a torcida." The term "palmeirense" is used to refer to Palmeiras' supporters, a Brazilian soccer team, whose mascot is a pig.
} 
(B.3) The two words (prostitute and police), connected by the "and" connector are placed in a relation of parallelism, which, beyond to establish a comparison between the two elements, ideologically connect them.

When the receiver takes these three hypotheses (B), they explain, by an inference drawn from a contextual assumption (CA), the utterance of the bumper. Thus, two implicated premises (IP) are extracted:

(B.4) The truck driver treats prostitutes and police, putting them on the same moral plane;

(B.5) The truck driver refuses to transport prostitutes and police, because they have prejudice against both.

From the encyclopaedic entries the following assumptions are also made (CA):

(C.1) The patrolman has the authority to reprimand the driver and tell him to erase what is written on his truck's bumper;

(C.2) The patrolman really threatens the driver: if he does not respect the orders of the police, your truck will be arrested.

According to the information of these utterances, new contextual assumptions (CA) can be drawn about the new phrase that the driver wrote down on his truck bumper:

(D.1) He explicitly says that he carried out what the police forced him to do.

(D.2) He implies that their prejudices remain unchanged.

We arrive finally at the following implicated assumptions (IA), which will be subjected to the criteria of the truth value of these assertions, also noting its strength from the way they were acquired.

IP.1 - The truck driver obeyed the patrolman's command to erase the provocative phrase True.

IP.2 - The truck driver obeyed the patrolman's order to not speak his prejudices - False.

Remember that when the deductive mechanism operates in a synthetic rule and one of the premises is true and other is false, the conclusion inherits its strength from the weaker premise. IP.1 is the stronger premise because it results from a visual stimulus, since we can "see" that the phrase of the bumper truck was changed; while IP.2 is the weaker premise, because it's necessary a deduction, which requires shared encyclopaedic knowledge by the patrolman and the truck driver, which is the previous sentence and the requirement made by the highway patrolman.

One gets thus the implied conclusion (IC):

IC - The truck driver doesn't let his explicit prejudice, but the patrolman knows it. 
Judging that the implied conclusion (IC) does not make the paradox clear, I always suggest include the "paradoxical implied conclusion" - PIC: "The patrolman 'reads' the prejudiced phrase that was written on truck's bumper was erased by the truck's driver bumper." I note how would be this final element, with bisociation always in the intersection of the initial graphic schemes (Figure 3):

\section{Figure 3 - A schematic representation of bisociative joke (5)}

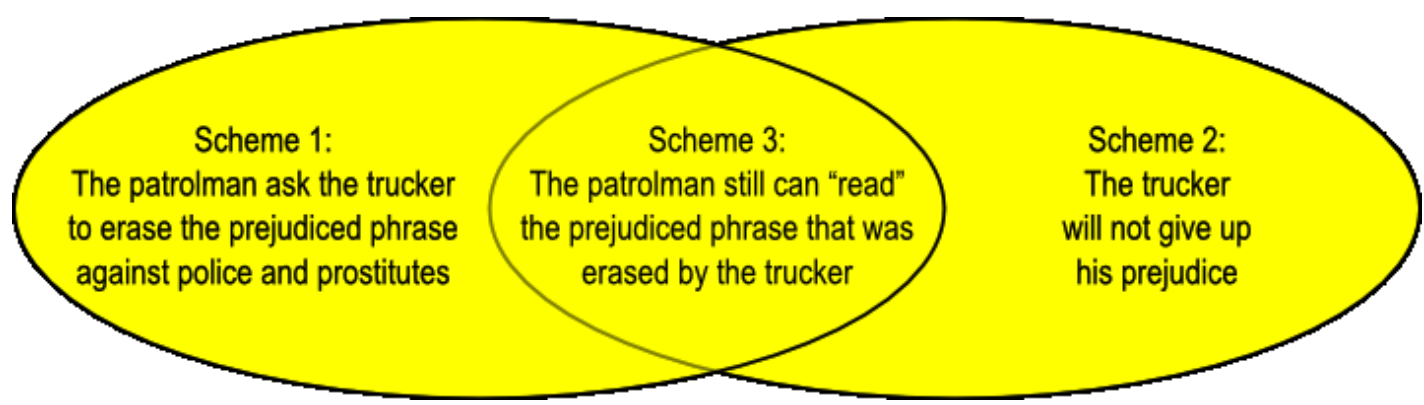

It should be made clear that the schematized mechanism only shows the phenomenon of bisociation and that, to explain the process/development of interpretation, the text should treat as was done with the joke above, demonstrating that the context is constructed as the interpretation evolves, and each new utterance makes use of previously contextualized information.

\section{CONCLUSION}

Relevance theory offers to the reader a methodological approach for text processing: aiming to find an interpretation that satisfies their expectation of optimal relevance, as proposed in the following excerpt from Wilson (2004, lesson 5, p. 1):

\footnotetext{
Relevance-theoretic comprehension procedure

Follow a path of least effort in computing cognitive effects:

2a Consider interpretations in order of accessibility;

$2 b$ Stop when your expectation of relevance is satisfied.
}

Blakemore (2005/1992, p. 31) draws attention to the fact that, although it could continue indefinitely: "Althoug processing could in principle go on for ever, it has to stop somewhere. But where? Intuitively, the answer is clear: where the processor thinks it is no longer worth the effort." In the joke, it is the understanding and acceptance of paradox as such that ends the interpretation. From this perspective, I disagree with the proposal of understanding the mechanism of the joke by a process of "coherentisation" of the paradox: it would be like dissecting a surrealist painting, trying to give it "coherence." I believe that the understanding of the paradox is obtained by the seizure 
of contextual implications (premises) that arise from the fusion of contextual assumptions which, alone, would be achieved within the foreseeable sequences, but they come together to enrich the unprecedented, indecomposable and irreversible idea that emerge as a third cognitive schema. This idea imposes itself by force of contextual effects that come from it, just to be paradoxical, weaken other assumptions that were being contemplated at that point of interpretation. And contrary to the pursuit of human beings balance, the paradox is) precisely created to destabilize structures, awakening individuals to the incongruities of social systems in which they are inserted.

I even believe the model that I propose to describe the mechanism of humour also covers the "improvisational jokes," since the conditions of this model are fulfilled: the creation of a paradox whose strength exceeds the interpretation which had been processed before.

I think there's in a joke an "adequacy" between form and thematic content, which is just caused by the fact that, by violating the "incongruities" of the social system, the individuals make use of a mechanism whose formal structure also uses the incongruity: it is formal and apparent incongruity denouncing the actual incongruity of the rules of conviviality or of social contact of the system. It is this "adequacy" between form and content associated to surprise that, along with the reasoning, contribute to the cognitive pleasure and are in the basis of humour, playing a dual role: on one hand, to let the reader to participate of "accusations" against the rules of social convention and, on the other hand, to require from him a thought that clashes with a paradox, which increases the pleasure of the joke.

\section{REFERENCES}

BLAKEMORE, Diane. Understanding Utterances. Oxford: Blackwell Publishing, 2005 (1992).

CURCÓ, Carmen. The Implicit Expression of Attitudes, Mutual Manifestness, and Verbal Humour. In: YUS RAMOS, Francisco. Humour and the Search for Relevance. Alicante: Department of English Studies, University of Alicante, Spain, 2003. p. 1295-1331.

CURSINO-GUIMARÃES, S. Do desafio do humour à sedução do processamento do texto humorístico à luz da Teoria da Relevância. 378p. Tese (Doutorado em Linguística)-Faculdade de Letras, Universidade Federal de Minas Gerais, 2008.

ECO, Umberto. O cômico e a regra. In: ___ Viagem na irrealidade cotidiana. Rio de Janeiro: Nova Fronteira, 1984. p. 343-353.

FESTINGER, L. A Theory of Cognitive Dissonance. Stanford: Stanford University, 1957.

FOURASTIÉ, Jean. Le rire, suite. Paris: Denoël/Gonthier, 1983.

GUILFORD, Joy Paul. Creativity Toys. New York, 1982.

GRICE, H. P. Lógica e Conversação. In: DASCAL, Marcelo (Org.): Fundamentos Metodológicos da Linguistica. V. IV - Pragmática. Translated by João Wanderley Geraldi. Campinas: Unicamp, 1982 [1975]. p. 81-103.

KERBRAT-ORECCHIONI, Catherine. L'implicite. Paris: Armand Colin, 1998/1986.

KOESTLER, Arthur. The Act of Creation. New York: Dell Publishing Co., Inc. 1964.

NOGUEZ, Dominique. L'humour ou la dernière des tristesses. Études françaises, v. 5, n. 2, p. 139-161, 1969. Disponível em: http://id.erudit.org/iderudit/036386ar. Access in: jun. 2008.

OLBRECHTS-TYTECA, Lucie. Le comique du discours. Bruxelles: Institut de Sociologie de l’Université de Bruxelles, 1974. 
RASKIN, Victor. Semantic Mechanisms of Humour. Dordrecht and Boston: D. Reidel, 1985.

RAUEN, Fábio José. Processos interacionais entre discentes /docentes em espaço virtual de aprendizagem: análise com base na teoria da relevância. Scripta, Belo Horizonte, v. 12, n. 22, p. 190-217, 2008.

REBOUL, Anne; MOESCHLER, Jacques. Pragmatique du discours: de l'interprétation de l'énoncé à l'interprétation du discours. Paris: Armand Colin, 2005/1998.

RÉCANATI, François. La transparence et l'énonciation: pour introduire à la pragmatique. Paris: Seuil, 1979.

SPERBER, Dan; WILSON, Deirdre. Relevance: communication $\&$ cognition. $2^{\text {nd }}$ ed. Cambridge, MA: Harvard University, 1995 ( $1^{\text {st }}$ ed.1986).

Teoria da Relevância. Translated by Fábio José Rauen and Jane Rita Caetano da Silveira Linguagem em (Dis)curso, v. 5, n. especial, Tubarão, p. 221-263, 2005. Available at: $<$ http://www3.unisul.br/paginas/ensino/pos/linguagem/0403/00.htm>. Access on: 10 Aug. 2007.

. Posfácio da edição de 1995 de Relevância: comunicação \& cognição. Translated by Fábio José Rauen and Jane Rita Caetano da Silveira. Linguagem em Discurso, v. 5, n. especial, Tubarão, p. 171-220, 2005. Available at: http:/www3.unisul.br/paginas/ensino/pos/linguagem/0403/00.htm. Acesso em: 15 ago. 2007. (Original: Postscript from the 1995 Edition of Relevance: Communication \& Cognition).

SULS, Jerry M. A two-stage model for the appreciation of jokes and cartoons: an information-processing analysis. In GOLDSTEIN, Jeffrey H., McGHEE, Paul E. (Ed.). The Psychology of Humour: Theoretical Perspectives and Empirical Issues. London: Academic Press, 1972. p. 81-100.

VOESE, Ingo. O discurso humorístico: um estudo introdutório. In Linguagem e humor, Revista Leitura: Estudos Linguísticos e Literários do Departamento de Letras Clássicas e Vernáculas, Maceió: CHLAUFAL, 1989/1990, p. 7-20.

VIDAL-ROSSET, Joseph. Qu'est-ce qu'un paradoxe? Paris: Librairie Philosophique J. Vrin, 2004.

WATZLAWICK, Paul; BEAVIN, Janet Helmick; JACKSON, Don D. Pragmática da comunicação humana: um estudo dos padrões, patologias e paradoxos da interação. Translated by: Álvaro Cabral. São Paulo: Cultrix, 1981. (Original: Pragmatics of Human Communication: Study of Interactional Patterning Pathologies, and Paradoxes. London: Faber and Faber, 1967).

WILSON, Deirdre. Pragmatic Theory. Lesson 5: Pragmatics and relevance. London: UCL Linguistics Dept., 2004. Available at: <htpp://www.phon.ucl.ac.uk/home/pragtheory/>. Access on: 15 mar. 2005

YUS RAMOS, Francisco. Humor and the Search for Relevance. Alicante: Department of English Studies, University of Alicante, Spain, 2003. p. 1295-1331.

Cooperación y relevancia: dos aproximaciones pragmáticas a la interpretación. Alicante:

Universidad de Alicante, Servicio de Publicaciones, 1997.

Recebido em 30/04/14. Aprovado em 30/09/14.

Título: O mecanismo do humor sob a perspectiva da teoria da relevância Autora: Sídnei Cursino-Guimarães

Resumo: Neste artigo, apresenta-se um modelo para explicar o mecanismo do humour, conciliando o conceito de bissociação com os princípios de interpretação que fundamentam a Teoria da Relevância, de Sperber e Wilson (1986). Sugiro que a elaboração do humor ocorre pelo recurso à bissociação, que, por sua vez, traduz-se pela junção de um entimema e um paradoxo e, para interpretar o resultado da fusão desses procedimentos lógicos, proponho sua análise com base na Teoria da Relevância. Desta teoria, utilizo os seguintes conceitos: suposições contextuais, premissas implicadas, conclusão implicada e proponho, ao final, o conceito de conclusão implicada paradoxal, um fenômeno que só ocorre no gênero humorístico.

Palavras-chave: Comunicação. Humor. Teoria da Relevância. Bissociação. Paradoxo. 
Título: El mecanismo de humor desde la perspectiva de la teoría de la relevancia Autor: Sídnei Cursino-Guimarães

Resumen: En este artículo se presenta un modelo para explicar el mecanismo del humor, que combina el concepto de bissociación con los principios de interpretación que subyacen a la teoría de la relevancia de Sperber y Wilson (1986). Sugiero que el desarrollo del humor se produce recurriendo a la bissociación, que, a su vez, se refleja en la unión de un entimema y una paradoja, y para interpretar el resultado de la fusión de estos procedimientos lógicos, propongo su análisis basado en la Teoría de la Relevancia. De esta teoría, uso los siguientes conceptos: supuestos contextuales, supuestos implicados, conclusión implicada y propongo, al final, el concepto de conclusión paradójica implícita, un fenómeno que sólo se produce en el género humorístico.

Palabras clave: Comunicación. Humor. Teoría de la Relevancia. Bissociación. Paradoja. 